\title{
Fischer-Tropsch Synthesis over Iron Manganese Catalysts: Effect of Preparation and Operating Conditions on Catalyst Performance
}

\author{
Ali A. Mirzaei, Samaneh Vahid, and Mostafa Feyzi \\ Department of Chemistry, Faculty of Sciences, University of Sistan and Baluchestan, Zahedan 98135-674, Iran \\ Correspondence should be addressed to Ali A. Mirzaei, mirzaei@hamoon.usb.ac.ir \\ Received 24 April 2008; Revised 24 June 2008; Accepted 20 July 2008 \\ Recommended by Hiroshi Onishi
}

Iron manganese oxides are prepared using a coprecipitation procedure and studied for the conversion of synthesis gas to light olefins and $\mathrm{C}_{5}{ }^{+}$hydrocarbons. In particular, the effect of a range of preparation variables such as $[\mathrm{Fe}] /[\mathrm{Mn}]$ molar ratios of the precipitation solution, $\mathrm{pH}$ of precipitation, temperature of precipitation, and precipitate aging times was investigated in detail. The results are interpreted in terms of the structure of the active catalyst and it has been generally concluded that the calcined catalyst (at $650^{\circ} \mathrm{C}$ for 6 hours) containing $50 \% \mathrm{Fe} / 50 \% \mathrm{Mn}$-on molar basis which is the most active catalyst for the conversion of synthesis gas to light olefins. The effects of different promoters and supports with loading of optimum support on the catalytic performance of catalysts are also studied. It was found that the catalyst containing $50 \% \mathrm{Fe} / 50 \% \mathrm{Mn} / 5 \mathrm{wt} . \% \mathrm{Al}_{2} \mathrm{O}_{3}$ is an optimum-modified catalyst. The catalytic performance of optimal catalyst has been studied in operation conditions such as a range of reaction temperatures, $\mathrm{H}_{2} / \mathrm{CO}$ molar feed ratios and a range of total pressures. Characterization of both precursors and calcined catalysts is carried out by powder X-ray diffraction (XRD), scanning electron microscopy (SEM), BET specific surface area and thermal analysis methods such as TGA and DSC.

Copyright (C) 2009 Ali A. Mirzaei et al. This is an open access article distributed under the Creative Commons Attribution License, which permits unrestricted use, distribution, and reproduction in any medium, provided the original work is properly cited.

\section{Introduction}

Fischer-Tropsch (FT) synthesis is of great industrial importance due to the great variety of products obtained such as paraffins, olefins and alcohols. An approach to improve the selectivity of the classical Fischer-Tropsch (FT) process for conversion of synthesis gas to hydrocarbons involves the use of a bifunctional catalyst system containing a metal catalyst (FT catalyst) combined with a support. There has been renewed interest in recent years in FT synthesis, especially for the selective production of petrochemical feedstocks such as ethylene, propylene, and buthylene $\left(\mathrm{C}_{2}-\mathrm{C}_{4}\right.$ olefins) directly from synthesis gas [1-7]. Compared to other metal catalysts for Fischer-Tropsch (FT) synthesis, an iron-based catalyst is distinguished by higher conversion, selectivity to the lower olefins, and flexibility to the process parameters $[8,9]$. However, the use of iron catalyst does not solve the problem of insufficient selectivity, which represents a general limitation of FT synthesis. Manganese has been widely used as one of the promoters for FTS on iron catalyst, particularly in producing low olefins [10-13]. Large efforts have also been exerted on the individual effect of manganese promotion on supported or unsupported iron catalysts $[13,14]$. Fe-Mn and Co-Mn catalysts favor $\mathrm{C}_{2}-\mathrm{C}_{4}$ olefins $[15,16]$. High $\mathrm{C}_{2}-\mathrm{C}_{4}$ selectivity for the iron-rich $\mathrm{Fe}-\mathrm{Mn}$ solid has been correlated with the iron manganese oxides phase and two carbide phases, while the manganese-rich solid has been correlated with two spinel phases and different carbide phases [11, 17]. The Fe-Mn catalyst, as one of the most important catalyst systems, has received extensive attention in recent years because of the higher olefin and middle distillation cut selectivities which allow their products to be used as a feedstock for the chemical industry. Therefore, the FeMn catalyst has a promising industrial application [18-22], and it is well known that higher selectivity of alkenes can be obtained on Fe/Mn catalysts than on other iron-based catalysts [23, 24]. The aim of this research work was to investigate the effect of a range of preparation variables including 
the precipitate aging time, $\mathrm{pH}$, temperature of precipitation, and the $[\mathrm{Fe}] /[\mathrm{Mn}]$ molar ratio of the precipitation solution of mixed iron manganese oxide catalysts. We also report further results concerning the effects of different promoters and supports along with loadings of $\mathrm{Al}_{2} \mathrm{O}_{3}$ as an optimum support on catalytic performance of this catalyst for FischerTropsch synthesis. In addition, the catalyst structural and morphological was investigated by XRD, SEM, BET, and thermal analysis methods such as TGA and DSC. Also, the effects of operation conditions such as $\mathrm{H}_{2} / \mathrm{CO}$ molar feed ratios, a range of reaction temperatures and total pressures for conversion of synthesis gas to light olefins have been studied.

\section{Experimental}

2.1. Catalyst Preparation. All the catalysts were prepared using the coprecipitation procedure. Aqueous solutions of $\mathrm{Fe}\left(\mathrm{NO}_{3}\right)_{3} \cdot 9 \mathrm{H}_{2} \mathrm{O}(0.5 \mathrm{M})$ (99\%, Merck, Germany) and $\mathrm{Mn}\left(\mathrm{NO}_{3}\right)_{2} \cdot 4 \mathrm{H}_{2} \mathrm{O}(0.5 \mathrm{M})$ (99.5\%, Merck, Germany) with different molar ratios were premixed and the resulting solution heated to $70^{\circ} \mathrm{C}$ in a round-bottomed flask fitted with a condenser. Aqueous $\mathrm{Na}_{2} \mathrm{CO}_{3}(0.5 \mathrm{M})(99.8 \%$, May \& Baker, France) was added dropwise to the mixed nitrate solution, which was continuously stirred whilst the temperature was maintained isothermally in the range of $40-80^{\circ} \mathrm{C}$. The final $\mathrm{pH}$ achieved was varied between 6.3 and 10.3. This procedure took approximately 10 minutes to complete. The resulting precipitate was then left in this medium at the required $\mathrm{pH}$ and temperature used for the precipitation for times ranging from 0 to 5 hours. The precipitate was first filtered and then washed several times with warm distilled water until no further $\mathrm{Na}^{+}$was observed in the washings tested by flam atomic absorption. The precipitate was then dried at $110^{\circ} \mathrm{C}$ for 16 hours to give a material denoted as the catalyst precursor which was subsequently calcined in static air in the furnace $\left(650^{\circ} \mathrm{C}, 6\right.$ hours $)$ to give the final catalyst. For preparation of the supported catalysts, the same amount (20 wt $\%)$ of each support such as $\mathrm{TiO}_{2}(98 \%$, May \& Baker), $\mathrm{SiO}_{2}$ (98\%, Merck), $\gamma-\mathrm{Al}_{2} \mathrm{O}_{3}$ (98\%, Merck), $\mathrm{MgO}$ (98\%, Merck), and ZSM-5 zeolite (99\%, Aldrich, UK) has been added separately to the mixed solution of iron and manganese nitrates with nominal ratio of $\mathrm{Fe} / \mathrm{Mn}=$ $1 / 1$. After the test of all these supported catalysts, it was found that $\mathrm{Al}_{2} \mathrm{O}_{3}$ is the best support than the others, so the $\mathrm{Al}_{2} \mathrm{O}_{3}$ loading of $5,10,15,20$, and $25 \mathrm{wt} \%$ based on the total catalyst weight, were used to obtain the best loading of $\mathrm{Al}_{2} \mathrm{O}_{3}$ support. The supported catalyst was then promoted with different promoters $(\mathrm{Li}, \mathrm{K}, \mathrm{Rb}$, and $\mathrm{Mg}$ ) by adding a small amount (1.5 wt\%) of $\mathrm{LiNO}_{3}(99.5 \%$, Prolabo, France), $\mathrm{KNO}_{3}$ (99\%, Merck), $\mathrm{RbCl}$ (99\%, Prolabo), and $\mathrm{Mg}\left(\mathrm{NO}_{3}\right)_{2} \cdot 6 \mathrm{H}_{2} \mathrm{O}(99 \%$, May \& Baker) as separately to the suspension containing $50 \% \mathrm{Fe} / 50 \% \mathrm{Mn} / 5 \mathrm{wt} . \% \mathrm{Al}_{2} \mathrm{O}_{3}$.

\subsection{Catalyst Characterization}

2.2.1. X-Ray Diffraction (XRD). Powder X-ray diffraction (XRD) measurements were performed using a Bruker Axs Company, D8 Advance diffractometer (Germany). Scans were taken with a $2 \theta$ stepsize of 0.02 and a counting time of 1 second using $\mathrm{CuK}_{\alpha}$ radiation source generated at $40 \mathrm{kV}$ and $30 \mathrm{~mA}$. Specimens for XRD were prepared by compaction into a glass-backed aluminum sample holder. Data was collected over a $2 \theta$ range from $4^{\circ}$ to $70^{\circ}$ and phases were identified by matching experimental patterns to entries in the Diffrac ${ }^{\text {plus }}$ Version 6.0 indexing software.

2.2.2. BET Measurements. Brunauer-Emmett-Teller surface area BET measurements were conducted using a micrometrics adsorption equipment (Quantachrome instrument, model Nova 2000, USA) determining nitrogen (99.99\% purity) as the analysis gas and the catalyst samples were slowly heated to 300 for 3 hours under nitrogen atmospheric. Prior to analysis each precursors and catalyst and after reaction catalysts measurements specific surface area was evacuated at $-196^{\circ} \mathrm{C}$ for 66 minutes.

\subsubsection{Thermal Gravimetric Analysis (TGA) and Differential} Scanning Calorimetriy (DSC). The TGA and DSC were carried out using simultaneous thermal analyzer apparatus of Rheometric Scientific Company (STA 1500+ Model, England) under a flow of dry air. The temperature was raised from $25^{\circ} \mathrm{C}$ to $800^{\circ} \mathrm{C}$ using a linear programmer at a heating rate of $10^{\circ} \mathrm{C} / \mathrm{min}$. The sample weight was between 10 and $20 \mathrm{mg}$.

2.2.4. Scanning Electron Microscopy (SEM). The morphology of catalysts and their precursors was observed by means of an S-360 Oxford Eng scanning electron microscopy (made in USA). All of the SEM images in this study are taken at the same magnification of $20 \mu \mathrm{m}$.

2.3. Catalyst Testing. The catalyst tests were carried out in a fixed bed stainless steel microreactor at different operation conditions (Figure 1). All gas lines to the reactor bed were made from $1 / 4^{\prime \prime}$ stainless steel tubing. Three mass flow controllers (Brooks, Model 5850E) equipped with a four-channel control panel (Brooks 0154) were used to adjust automatically the flow rate of the inlet gases $(\mathrm{CO}$, $\mathrm{H}_{2}$, and $\mathrm{N}_{2}$ with purity of $99.999 \%$ ). The mixed gases passed into the reactor tube, which was placed inside a tubular furnace (Atbin, Model ATU 150-15) capable of producing temperature up to $1300^{\circ} \mathrm{C}$ and controlled by a digital programmable controller (DPC). The reactor tube was constructed from $1 / 2^{\prime \prime}$ stainless steel tubing; internal diameter of $9 \mathrm{~mm}$, with the catalyst bed situated in the middle of the reactor. The reaction temperature was controlled by a thermocouple inserted into catalyst bed and visually monitored by a computer equipped with software. The meshed catalyst $(1.0 \mathrm{~g})$ was held in the middle of the reactor with $110 \mathrm{~cm}$ length using quartz wool. It consists of an electronic back pressure regulator which can control the total pressure of the desired process using a remote control via the TESCOM software package integration that improve or modify its efficiency that capable of working on pressure ranging from atmospheric pressure to 100 bar. The catalyst was pre-reduced in situ atmospheric pressure in a flowing 


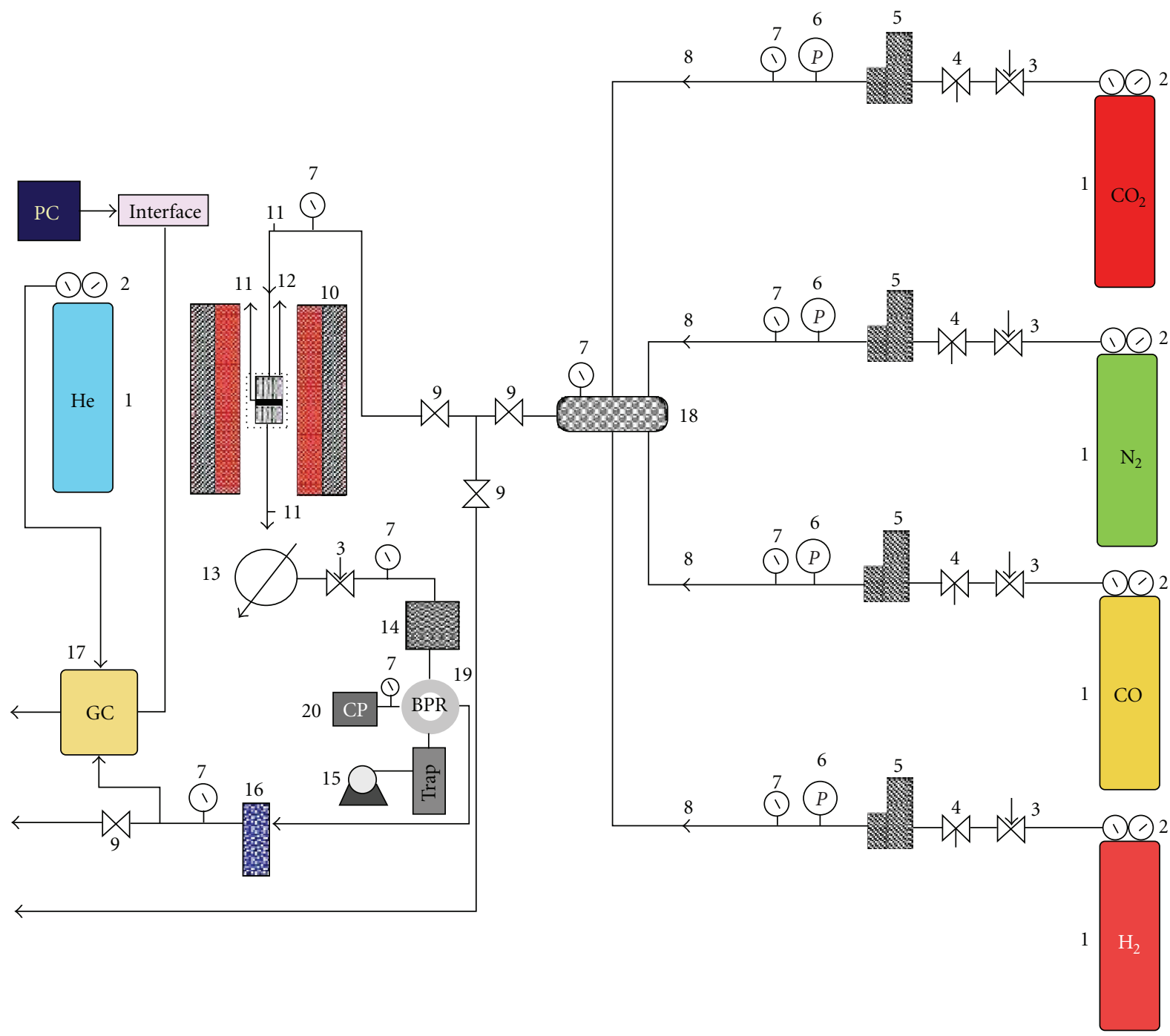

FIGURE 1: Schematic representation of the reactor in a flow diagram used. (1) Gas cylinders, (2) pressure regulators, (3) needle valves, (4) valves, (5) mass flow controllers (MFCs), (6) digital pressure controllers, (7) pressure Gauges, (8) nonreturn valves, (9) ball valves, (10) tubular furnace, (11) temperature indicators, (12) tubular reactor and catalyst bed, (13) condenser, (14) trap, (15) air pump, (16) silica gel column, (17) gas chromatograph (GC), (18) mixing chamber, (19) (BPR) back pressure regulator (electronically type), (20) control panel (CP).

$\mathrm{H}_{2}-\mathrm{N}_{2}$ stream $\left(\mathrm{N}_{2} / \mathrm{H}_{2}=1\right.$, flow rate of each gas $=30 \mathrm{~mL} /$ $\min )$ at $400^{\circ} \mathrm{C}$ for 6 hours before synthesis gas exposure. The FT reactions was carried out at $260-420^{\circ} \mathrm{C}(P=1-15$ bar, $\mathrm{H}_{2} / \mathrm{CO}=1 / 1-3 / 1$, GHSV $\left.=2700-5400 \mathrm{~h}^{-1}\right)$. Reactant and product streams were analyzed online using a gas chromatograph (Varian, Model 3400 Series) equipped with a 10port sampling valve (Supelco company, USA, Visi Model), a sample loop, and thermal conductivity detector (TCD). The contents of sample loop were injected automatically into a packed column (Hayesep DB, Altech Company, USA, 1/8" OD, 10 meters long, and particle mesh 100/120). Helium was employed as a carrier gas for optimum sensitivity (flow rate $=30 \mathrm{~mL} / \mathrm{min}$ ). The calibration was carried out using various calibration mixtures and pure compounds obtained from American Matheson Gas Company (USA). GC controlling and collection of all chromatograms was done via an IF-2000 single channel data interface (TG Co, Tehran, Iran) at windows environment. The results in terms of $\mathrm{CO}$ conversion, selectivity, and yield of products are given at each space velocity. The CO conversion (\%) is calculated according to the normalization method [25]:

$$
\text { CO conversion }(\%)=\frac{\left(\text { Moles } \mathrm{CO}_{\text {in }}\right)-\left(\text { Moles } \mathrm{CO}_{\text {out }}\right)}{\text { Moles } \mathrm{CO}_{\text {in }}} \times 100 \text {. }
$$

The selectivities (\%) toward the individual components on carbon basis are calculated according to the same principle [26]:

$$
\begin{aligned}
& \text { Selectivity of } j \text { product }(\%) \\
& \qquad=\frac{\text { Moles of } j \text { product }}{\left(\text { Moles } \mathrm{CO}_{\text {in }}\right)-\left(\text { Moles } \mathrm{CO}_{\text {out }}\right)} \times 100 \text {. }
\end{aligned}
$$




\section{Results and Discussion}

3.1. Effect of Preparation Conditions. In this part of study, we have investigated the effect of a range of iron manganese oxide catalysts preparation variables at the precursor stage upon the structure of these materials, and the subsequent influence these structural effects have on the activity of the final calcined catalysts. The optimum preparation conditions were identified with respect to the catalytic activity for the conversion of synthesis gas to light olefins.

3.1.1. Effect of Aging Time. Aging time is one of the most important factors on the catalytic performance of the catalyst and it was defined as the time between the formation of precipitate and the removal of solvent. In our previous study, we demonstrated the importance of aging time with respect to catalyst activity for oxidation of $\mathrm{CO}$ by mixed copper manganese oxide and mixed copper zinc oxide catalysts [27-35] and for hydrogenation of $\mathrm{CO}$ by mixed of cobalt-iron oxide, cobalt-manganese oxide, and cobaltcerium oxide catalysts for Fischer-Tropsch synthesis [3640]. In all of these investigations, our results have shown that the aging of the precipitates obtained by coprecipitation leads to phase changes toward the forms, which are more stable thermodynamically. In this study, to examine the effect of aging on the performance of iron manganese oxide catalysts for the hydrogenation of $\mathrm{CO}$, a series of mixed iron manganese oxide catalysts were prepared by coprecipitation method $\left([\mathrm{Fe}] /[\mathrm{Mn}]=1 / 1,70^{\circ} \mathrm{C}, \mathrm{pH}=8.3\right)$ with a range of aging times between 0 minute (unaged) and 300 minutes for the precipitate. The catalysts were prepared by calcination at $650^{\circ} \mathrm{C}$ for 6 hours and then were tested for hydrogenation of $\mathrm{CO}$. The effect of aging time on catalytic performance is shown in Table 1. These results show that there is a considerable variation in the catalyst performance with respect to aging time and the sample aged for 3 hours gave the optimal catalytic performance for $\mathrm{CO}$ conversion in FTS. Thus aging time is a parameter of crucial importance in the preparation of active mixed iron manganese oxide catalysts for the hydrogenation of CO. Characterization studies were carried out using various techniques for both the precursors and calcined catalysts. Characterization of precursors was studied to establish the importance of the structure of the catalyst precursor in controlling the structure of the final catalyst and consequently activity. The catalyst precursors which were prepared using coprecipitation method in different aging times were characterized by thermal gravimetric analysis (TGA) and the TGA curves of these precursors are displayed in Figure 2. For these precursors, the thermogravimetric curves seem to indicate three-stage decomposition. The first stage is considered to be due to the removal of adsorbed water $\left(40-110^{\circ} \mathrm{C}\right)$ and the second stage is due to the decomposition of hydroxyl bimetallic or nitrate precursor $\left(330-420^{\circ} \mathrm{C}\right)$, respectively. The peak around $550-630^{\circ} \mathrm{C}$ is due to the decomposition of $\mathrm{MnCO}_{3}$ or $\mathrm{Fe}_{2} \mathrm{CO}_{3}(\mathrm{OH})_{2}$ to oxides. The TGA curves are involved with total overall weight loss of ca. 18-23 wt.\%. The catalyst precursors were also characterized by XRD and similar phases were identified for these catalyst precursors
TABLE 1: Effect of aging times on the catalytic performance.

\begin{tabular}{lcccccc}
\hline & & \multicolumn{5}{c}{ Selectivity (\%) } \\
$\begin{array}{l}\text { Aging time } \\
\text { (minute) }\end{array}$ & $\begin{array}{c}\mathrm{CO} \text { conversion } \\
(\%)\end{array}$ & $\mathrm{CH}_{4}$ & $\mathrm{C}_{2} \mathrm{H}_{4}$ & $\mathrm{C}_{3} \mathrm{H}_{6}$ & $\mathrm{C}_{4} \mathrm{H}_{8}$ & $\mathrm{C}_{5}{ }^{+}$ \\
\hline 60 & 78.2 & 32.0 & 24.3 & 9.0 & 3.4 & 7.0 \\
120 & 87.3 & 22.2 & 30.1 & 10.2 & 3.7 & 7.3 \\
180 & 80.2 & 21.4 & 26.2 & 10.0 & 3.9 & 6.2 \\
240 & 72.1 & 27.4 & 23.2 & 8.5 & 2.4 & 6.9 \\
300 & 69.1 & 22.9 & 18.1 & 9.7 & 1.5 & 6.1 \\
\hline
\end{tabular}

with preparation ratios $\left(\mathrm{MnCO}_{3}\right.$ (rhombohedral). The X-ray diffraction patterns for their calcined samples were similar together, although the relative diffracted intensities from the phases were slightly different and their patterns are illustrated in Figure 3. The actual phases identified in these calcined catalysts under the specified preparation conditions were $\mathrm{Mn}_{2} \mathrm{O}_{3}$ (cubic) and $\mathrm{Fe}_{2} \mathrm{O}_{3}$ (rhombohedral). Note that during the calcination of the precursors, the carbonate phases disappeared and oxide phases were formed. Some of these calcined catalysts were characterized by DSC method and their DSC curves are presented in Figure 4. These curves show that the catalysts have high-heat conductivity; this important case for the FTS catalysts is necessary to conduct the produced heat of reaction. Also, the absence of peaks on the DSC curves showed that the calcined catalysts have high-heat stability and it might be a reason why $650^{\circ} \mathrm{C}$ has been chosen for calcination of catalysts. In order to identify the changes in the tested catalysts during the reaction and to detect the phases formed; these catalysts were characterized by XRD after the test. The actual phases identified in these catalysts are presented in Table 2. As it shown, all of these tested catalysts have the $\mathrm{MnO}$ and $\mathrm{FeO}$ and iron carbide phases, which all of these phases are active in FTS. MnO is the active phase for production of olefins and iron carbide is the active phase for hydrogenation of CO. Characterization of both precursors and calcined catalysts for the series of differently aged samples (before and after reaction) was carried out using BET surface area and the results are listed in Table 3 . These results illustrated that increasing the aging time produced higher surface area materials. The $50 \% \mathrm{Fe} / 50 \% \mathrm{Mn}$ calcined catalyst aged for 180 minutes was the most active for conversion of synthesis gas to light olefins. This catalyst has almost a high-specific surface area; it is, therefore, considered that the higher activity of $50 \% \mathrm{Fe} / 50 \% \mathrm{Mn}$ catalyst may be attributed to its high BET surface area.

3.1.2. Effect of Precipitation $p H$. A series of iron manganese oxide catalysts were prepared by coprecipitation method $\left([\mathrm{Fe}] /[\mathrm{Mn}]=1 / 1,70^{\circ} \mathrm{C}, 3\right.$ hours aging time $)$ with a range of precipitation $\mathrm{pH}$ from 6.3 to 10.3 . The catalysts precursors, prepared using coprecipitation procedure in different $\mathrm{pH}$, were characterized by XRD and showed the $\mathrm{MnCO}_{3}$ phase as rhombohedral structure. The catalytic activity for the Fischer-Tropsch synthesis was investigated for the materials following calcination $\left(650^{\circ} \mathrm{C}, 6\right.$ hours $)$ and 


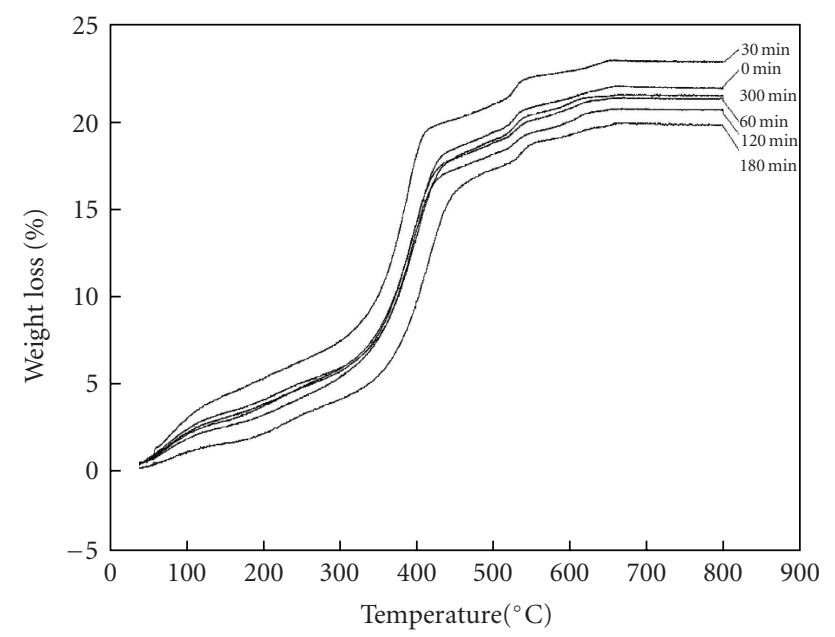

FIGURE 2: TGA curves of the catalyst precursors with different aging times.

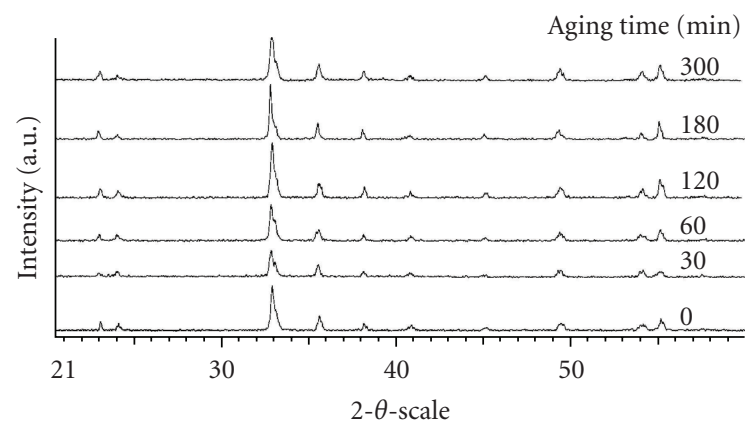

FIGURE 3: XRD patterns of the calcined catalysts with different aging times.

TABle 2: Different identified phases in the calcined catalysts with different aging times.

\begin{tabular}{|c|c|}
\hline $\begin{array}{l}\text { Aging time } \\
\text { (minute) }\end{array}$ & Phases \\
\hline 0 & $\begin{array}{l}\mathrm{MnO} \text { (cubic), } \mathrm{FeO} \text { (cubic), } \mathrm{Fe}_{2} \mathrm{C} \text { (orthorhombic), } \\
\mathrm{CFe}_{2.5} \text { (monoclinic) }\end{array}$ \\
\hline 30 & $\begin{array}{l}\mathrm{MnO} \text { (cubic), } \mathrm{FeO} \text { (cubic), } \mathrm{Fe}_{2} \mathrm{C} \text { (orthorhombic), } \\
\mathrm{CFe}_{2.5} \text { (monoclinic) }\end{array}$ \\
\hline 60 & $\begin{array}{l}\mathrm{MnO} \text { (cubic), } \mathrm{FeO} \text { (cubic), } \mathrm{Fe}_{2} \mathrm{C} \text { (orthorhombic), } \\
\mathrm{CFe}_{2.5} \text { (monoclinic) }\end{array}$ \\
\hline 120 & $\mathrm{CFe}_{2.5}$ (monoclinic), $\mathrm{MnO}$ (cubic), $\mathrm{FeO}$ (cubic) \\
\hline 180 & $\begin{array}{l}\mathrm{MnO} \text { (cubic), } \mathrm{FeO} \text { (cubic), } \mathrm{CFe}_{2.5} \text { (monoclinic), } \mathrm{Fe} \\
\text { (cubic) }\end{array}$ \\
\hline 300 & $\mathrm{CFe}_{2.5}$ (monoclinic), $\mathrm{MnO}$ (cubic), $\mathrm{FeO}$ (cubic) \\
\hline
\end{tabular}

the effect of precipitation $\mathrm{pH}$ on the catalytic performance is shown in Table 4. It is apparent that during precursor calcination, carbonate phase leads to the oxide phases and the sample prepared at $\mathrm{pH}=8.3$ gives the highest activity. These calcined catalysts were characterized by XRD and their patterns are shown in Figure 5. The actual phases identified in these catalysts were $\mathrm{Mn}_{2} \mathrm{O}_{3}$ (cubic) and $\mathrm{Fe}_{2} \mathrm{O}_{3}$

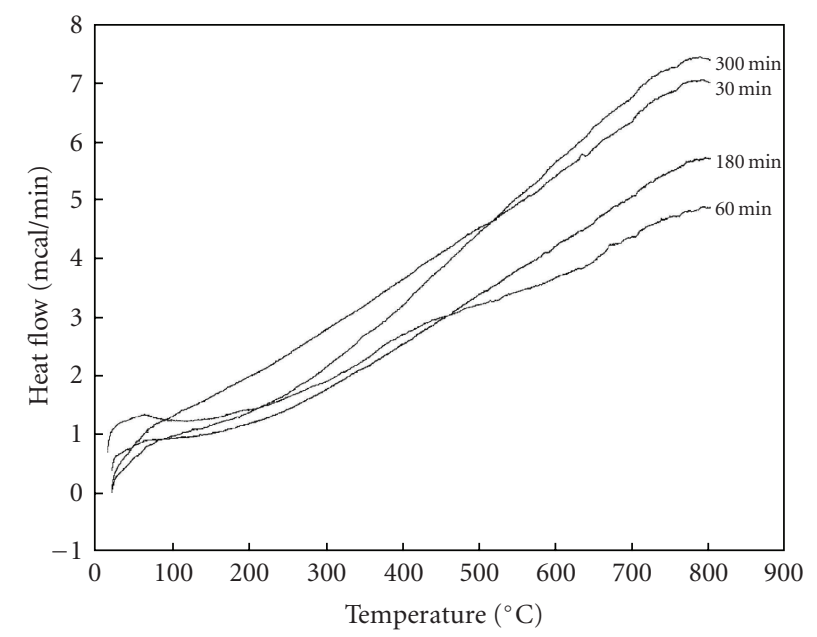

FIGURE 4: DSC curves of some calcined catalysts with different aging times.

TABLE 3: BET results for catalysts containing 50\%Fe/50\%Mn with different aging times.

\begin{tabular}{|c|c|c|c|}
\hline \multirow[b]{2}{*}{$\begin{array}{l}\text { Aging time } \\
\text { (minute) }\end{array}$} & \multicolumn{3}{|c|}{ Specific surface area $\left(\mathrm{m}^{2} / \mathrm{g}\right)$} \\
\hline & Precursor & $\begin{array}{l}\text { Calcined catalyst } \\
\text { (before reaction) }\end{array}$ & $\begin{array}{c}\text { Calcined catalyst } \\
\text { (after reaction) }\end{array}$ \\
\hline 0 & 85.0 & 82.3 & 79.1 \\
\hline 30 & 89.3 & 84.2 & 80.5 \\
\hline 60 & 93.2 & 86.6 & 82.7 \\
\hline 120 & 107.9 & 98.6 & 95.6 \\
\hline 180 & 115.8 & 113.1 & 109.5 \\
\hline 300 & 119.0 & 115.6 & 112.9 \\
\hline
\end{tabular}

TABLE 4: Effect of precipitation $\mathrm{pH}$ on the catalytic performance.

\begin{tabular}{lcccccc}
\hline \multirow{2}{*}{$\mathrm{pH}$} & CO conversion (\%) & \multicolumn{5}{c}{ Selectivity (\%) } \\
& & $\mathrm{CH}_{4}$ & $\mathrm{C}_{2} \mathrm{H}_{4}$ & $\mathrm{C}_{3} \mathrm{H}_{6}$ & $\mathrm{C}_{4} \mathrm{H}_{8}$ & $\mathrm{C}_{5}{ }^{+}$ \\
\hline 6.3 & 84.0 & 43.0 & 19.6 & 8.4 & 1.5 & 5.3 \\
7.3 & 79.6 & 27.9 & 19.0 & 9.0 & 2.7 & 7.2 \\
8.3 & 86.3 & 22.5 & 32.1 & 10.8 & 4.1 & 6.8 \\
9.3 & 81.2 & 20.0 & 24.1 & 10.0 & 4.0 & 5.9 \\
10.3 & 80.0 & 19.0 & 22.9 & 10.9 & 3.2 & 6.1 \\
\hline
\end{tabular}

(rhombohedral). The calcined tested catalysts prepared at $\mathrm{pH}=8.3$ also were characterized by XRD and different phases including $\mathrm{MnO}$ (cubic), $\mathrm{FeO}$ (cubic), and $\mathrm{CFe}_{2.5}$ (monoclinic) were identified in this catalyst. Note that in the tested catalyst, the oxidic and carbide phases are formed which both of them are active in FTS $[41,42]$.

3.1.3. Effect of Solution [Fe]/[Mn] Ratio. Iron manganese oxide catalysts were prepared by coprecipitation method $\left(70^{\circ} \mathrm{C}, \mathrm{pH}=8.3,3\right.$ hours aging time $)$ with a range of $[\mathrm{Fe}] /[\mathrm{Mn}]$ solution ratios varying from $100 \% \mathrm{Fe}$ to $100 \% \mathrm{Mn}$ and the catalytic performance for the Fischer-Tropsch 


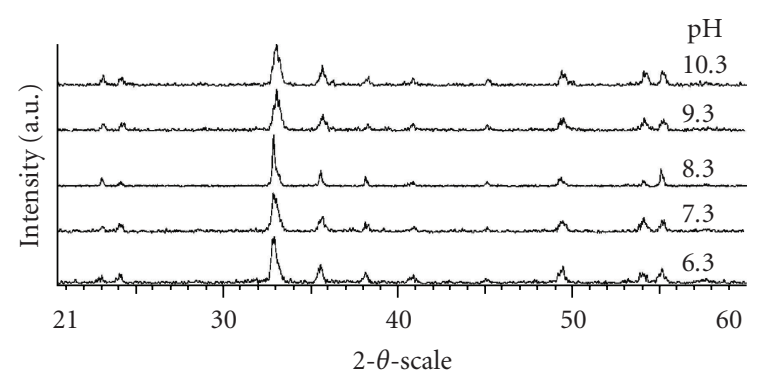

FIGURE 5: XRD patterns of calcined catalysts with different precipitation $\mathrm{pH}$.

synthesis was investigated for the materials following calcination $\left(650^{\circ} \mathrm{C}, 6\right.$ hours $)$. The $\mathrm{CO}$ conversion and hydrocarbons selectivity percent present on steady-state catalytic performance under comparable reaction conditions for the ironmanganese oxide catalysts with different $[\mathrm{Fe}] /[\mathrm{Mn}]$ molar ratios are shown in Table 5. The catalyst precursors prepared using coprecipitation method in different $[\mathrm{Fe}] /[\mathrm{Mn}]$ ratios and their calcined catalysts were characterized by XRD. The catalyst precursor containing $100 \% \mathrm{Fe}-0 \% \mathrm{Mn}$ was found to be amorphous and the other precursors showed the $\mathrm{MnCO}_{3}$ phase as rhombohedral structure. The XRD patterns of the different calcined catalysts with different $[\mathrm{Fe}] /[\mathrm{Mn}]$ molar ratios are presented in Figure 6. In the calcined catalyst containing $100 \% \mathrm{Fe}-0 \% \mathrm{Mn}$, the $\mathrm{Fe}_{2} \mathrm{O}_{3}$ (rhombohedral) phase was observed and in the calcined catalyst containing $0 \% \mathrm{Fe}-100 \% \mathrm{Mn}$, the $\mathrm{Mn}_{2} \mathrm{O}_{3}$ (cubic) phase was identified. For the other calcined catalysts, different phases including $\mathrm{Mn}_{2} \mathrm{O}_{3}$ (cubic) and $\mathrm{Fe}_{2} \mathrm{O}_{3}$ (rhombohedral) were identified. In order to identify the changes in the catalyst containing $50 \% \mathrm{Fe} / 50 \% \mathrm{Mn}$ during the reaction and to detect the phases formed, this catalyst was characterized by XRD after the test. Its phases were found to be $\mathrm{MnO}$ (cubic), $\mathrm{FeO}$ (cubic), and $\mathrm{CFe}_{2.5}$ (monoclinic). Characterization of these calcined catalysts was carried out using the BET surface area measurements and obtained results are presented in Table 6. The BET results show that the calcined catalysts prepared with a range of $[\mathrm{Fe}] /[\mathrm{Mn}]$ solution ratios varying from $100 \% \mathrm{Fe}$ to $100 \% \mathrm{Mn}$ have different specific surface areas. The catalyst with $1 / 1[\mathrm{Fe}] /[\mathrm{Mn}]$ ratio has a higher specific surface area than the other catalysts (Table 6), which is one reason for the enhanced performance of this catalyst [43]. According to the obtained results (Table 5), since the catalyst with preparation ratio of $1 / 1[\mathrm{Fe}] /[\mathrm{Mn}]$ showed the highest selectivity toward both ethylene and propylene, so the catalyst prepared with this molar ratio was chosen as the best catalyst for the conversion of synthesis gas to ethylene and propylene under reaction conditions $(P=$ $\left.1 \mathrm{~atm}, T=400^{\circ} \mathrm{C}, \mathrm{H}_{2} / \mathrm{CO}=2 / 1\right)$. The specific surface areas (BET) results of the precursors and calcined catalysts (before and after reaction) for different $\mathrm{Fe} / \mathrm{Mn}$ molar ratio are given in Table 6. Monometallic $100 \% \mathrm{Fe}$ is used as the basis for comparing the physical characteristics and $\mathrm{CO}$ hydrogenation performance and selectivity for the bimetallic Fe-Mn catalysts. As shown in Table 6, the BET surface areas

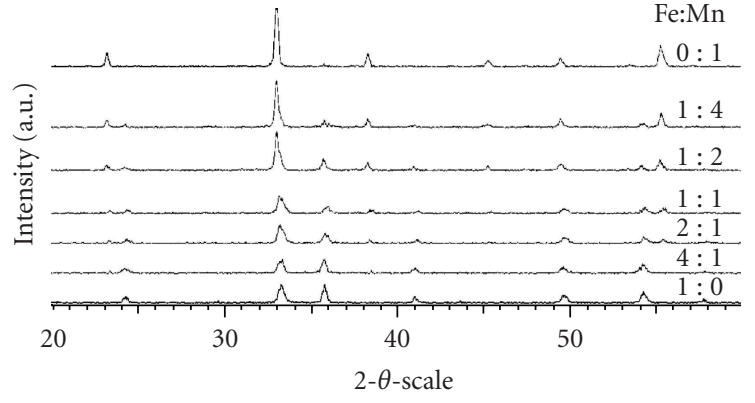

FIGURE 6: XRD patterns of calcined catalysts with different Fe/Mn molar ratios.

TABLE 5: Effect of Fe/Mn molar ratio on the catalytic performance.

\begin{tabular}{lcccccc}
\hline \multirow{2}{*}{ Fe/Mn } & \multirow{2}{*}{ CO conversion (\%) } & \multicolumn{5}{c}{ Selectivity (\%) } \\
& & $\mathrm{CH}_{4}$ & $\mathrm{C}_{2} \mathrm{H}_{4}$ & $\mathrm{C}_{3} \mathrm{H}_{6}$ & $\mathrm{C}_{4} \mathrm{H}_{8}$ & $\mathrm{C}_{5}{ }^{+}$ \\
\hline $1 / 0$ & 44.3 & 33.0 & 18.6 & 7.4 & 2.9 & 4 \\
$4 / 1$ & 59.1 & 32.2 & 20.1 & 8.6 & 3.7 & 4.9 \\
$2 / 1$ & 66.1 & 25.5 & 31.2 & 8.8 & 3.9 & 4.5 \\
$1 / 1$ & 81.2 & 20.0 & 24.1 & 10.0 & 4.0 & 6.3 \\
$1 / 2$ & 80.7 & 20.4 & 22.6 & 9.6 & 3.3 & 5.7 \\
$1 / 4$ & 79.2 & 21.3 & 21.8 & 9.2 & 3.7 & 7.1 \\
$0 / 1$ & 72.0 & 23.4 & 22.7 & 9.6 & 4.0 & 8.9 \\
\hline
\end{tabular}

TABLE 6: BET results for different molar ratios of Fe/Mn.

\begin{tabular}{|c|c|c|c|}
\hline \multirow{2}{*}{$\mathrm{Fe} / \mathrm{Mn}$} & \multicolumn{3}{|c|}{ Specific surface area $\left(\mathrm{m}^{2} / \mathrm{g}\right)$} \\
\hline & Precursor & $\begin{array}{l}\text { Calcined catalyst } \\
\text { (before reaction) }\end{array}$ & $\begin{array}{l}\text { Calcined catalyst } \\
\text { (after reaction) }\end{array}$ \\
\hline $1 / 0$ & 65.1 & 62.7 & 59.3 \\
\hline $4 / 1$ & 71.2 & 68.2 & 66.4 \\
\hline $2 / 1$ & 98.1 & 96.7 & 84.3 \\
\hline $1 / 1$ & 107.9 & 98.6 & 95.6 \\
\hline $1 / 2$ & 109.8 & 104.7 & 102.1 \\
\hline $1 / 4$ & 111.3 & 108.9 & 106.1 \\
\hline $0 / 1$ & 110.8 & 107.9 & 105.6 \\
\hline
\end{tabular}

for the catalysts prepared from different iron/manganese molar ratios are dependent on the Fe/Mn solution ratios. However, the specific surface area of catalyst precursor and calcined catalysts before reaction for each molar ratio were found to be nearly similar, the BET specific surface areas of the catalysts before and after reaction are different and the specific surface areas of all the calcined catalysts after reaction were decreased. The BET data for the catalysts containing $50 \% \mathrm{Fe} / 50 \% \mathrm{Mn}$ showed the high-specific surface area $\left(98.6 \mathrm{~m}^{2} / \mathrm{g}\right.$ for calcined catalyst) this might be a reason why the $50 \% \mathrm{Fe} / 50 \% \mathrm{Mn}$ catalyst shows a better catalytic performance than the other catalysts.

3.1.4. Effect of Precipitation Temperature. Iron manganese oxide catalysts were prepared by coprecipitation ([Fe]/ $[\mathrm{Mn}]=1 / 1, \mathrm{pH}=8.3,3$ hours aging time) with a range 
TABLE 7: Effect of preparation temperature on the catalytic performance.

\begin{tabular}{lcccccc}
\hline \multirow{2}{*}{$T\left({ }^{\circ} \mathrm{C}\right)$} & CO conversion (\%) & \multicolumn{5}{c}{ Selectivity $(\%)$} \\
& $\mathrm{CH}_{4}$ & $\mathrm{C}_{2} \mathrm{H}_{4}$ & $\mathrm{C}_{3} \mathrm{H}_{6}$ & $\mathrm{C}_{4} \mathrm{H}_{8}$ & $\mathrm{C}_{5}{ }^{+}$ \\
\hline 40 & 52.3 & 29.7 & 18.5 & 8.5 & 2.8 & 5.4 \\
50 & 61.5 & 29.5 & 22.8 & 10.1 & 3.5 & 6.1 \\
60 & 71.0 & 32.5 & 27.5 & 10.0 & 4.1 & 5.9 \\
70 & 81.2 & 20.0 & 24.1 & 10.0 & 4.0 & 6.3 \\
80 & 78.1 & 25.9 & 30.3 & 11.1 & 4.0 & 7.2 \\
\hline
\end{tabular}

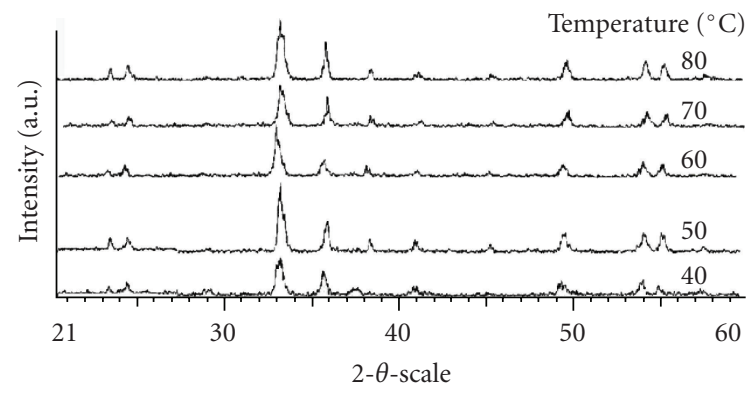

FIGURE 7: XRD patterns of calcined catalysts with different preparation temperatures.

of solution temperature from 40 to $80^{\circ} \mathrm{C}$. The catalytic performance of these series catalysts for the conversion of synthesis gas to light olefins was investigated for the materials following calcination $\left(650^{\circ} \mathrm{C}, 6\right.$ hours). The $\mathrm{CO}$ conversion and hydrocarbons selectivity percent present on steadystate catalytic performance for the iron manganese oxide catalysts with different solution temperature in reaction conditions $\left(P=1 \mathrm{~atm}, T=400^{\circ} \mathrm{C}, \mathrm{H}_{2} / \mathrm{CO}=2 / 1\right)$ are shown in Table 7. According to the obtained results, the percent of $\mathrm{CO}$ conversion was partially changed with the change of precipitation temperature and $70^{\circ} \mathrm{C}$ is considered to be practical maximum precipitation temperature and in this study, it was chosen as the optimum temperature for the catalysts preparation. The XRD patterns of catalyst precursors prepared by varying the temperature of the aging solution all showed similar diffraction patterns, the materials were poorly crystalline and comprised the $\mathrm{MnCO}_{3}$ phase with rhombohedral structure. The calcined catalysts were characterized by XRD and their patterns are presented in Figure 7. The XRD patterns of the calcined samples were similar to each other, although the relative diffracted intensities from the phases were slightly different. The actual phases identified in these catalysts under the specified preparation conditions were $\mathrm{Mn}_{2} \mathrm{O}_{3}$ (cubic), $\mathrm{Fe}_{2} \mathrm{O}_{3}$ (rhombohedral), and $\mathrm{MnO}_{2}$ (tetragonal).

3.1.5. Effect of Different Supports and Support Loadings. Hydrogenation of carbon monoxide is susceptible to metal support effects, and both specific activity and selectivity can be markedly influenced by both the metal and the support $[44,45]$. In order to study the effect of some supports such as $\mathrm{TiO}_{2}, \mathrm{SiO}_{2}, \mathrm{Al}_{2} \mathrm{O}_{3}, \mathrm{MgO}$, and zeolite into

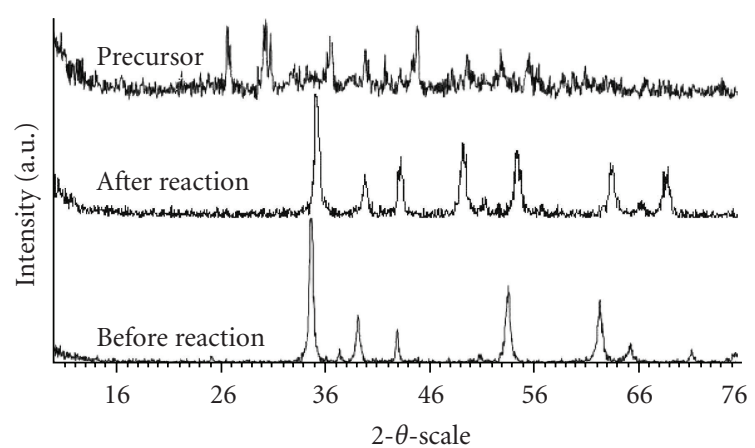

FIGURE 8: XRD patterns of the catalyst containing $\mathrm{Al}_{2} \mathrm{O}_{3}$ support in different states (precursor, calcined catalyst before and after the test).

TABLE 8: Effect of different supports on the catalytic performance.

\begin{tabular}{lcccccc}
\hline \multirow{2}{*}{ Support } & CO conversion (\%) & \multicolumn{5}{c}{ Selectivity (\%) } \\
& & $\mathrm{CH}_{4}$ & $\mathrm{C}_{2} \mathrm{H}_{4}$ & $\mathrm{C}_{3} \mathrm{H}_{6}$ & $\mathrm{C}_{4} \mathrm{H}_{8}$ & $\mathrm{C}_{5}{ }^{+}$ \\
\hline $\mathrm{TiO}_{2}$ & 61.3 & 21.5 & 23.6 & 8.2 & 2.4 & 5.8 \\
Zeolite & 70.5 & 27.6 & 22.3 & 9.3 & 3.1 & 6.3 \\
$\mathrm{MgO}$ & 67.8 & 36.5 & 20.9 & 8.4 & 2.3 & 4.7 \\
$\mathrm{Al}_{2} \mathrm{O}_{3}$ & 80.9 & 30.5 & 34.7 & 12.5 & 5.4 & 7.1 \\
Silica & 73.2 & 29.9 & 30.1 & 10.4 & 4.5 & 2.1 \\
\hline
\end{tabular}

TABLE 9: Effect of loading of $\mathrm{Al}_{2} \mathrm{O}_{3}$ on the catalytic performance.

\begin{tabular}{lcccccc}
\hline & & \multicolumn{5}{c}{ Selectivity (\%) } \\
$\mathrm{Al}_{2} \mathrm{O}_{3}(\mathrm{Wt} \%)$ & CO conversion (\%) & $\mathrm{CH}_{4}$ & $\mathrm{C}_{2} \mathrm{H}_{4}$ & $\mathrm{C}_{3} \mathrm{H}_{6}$ & $\mathrm{C}_{4} \mathrm{H}_{8}$ & $\mathrm{C}_{5}{ }^{+}$ \\
\hline 5 & 80.9 & 30.5 & 34.7 & 12.5 & 5.4 & 2.5 \\
10 & 75.9 & 51.0 & 18.4 & 7.8 & 3.9 & 5.0 \\
15 & 80.0 & 57.3 & 15.2 & 7.5 & 4.3 & 4.5 \\
20 & 82.2 & 40.6 & 27.2 & 10.2 & 4.2 & 5.8 \\
25 & 67.5 & 50.0 & 17.5 & 8.0 & 3.7 & 7.8 \\
30 & 60.9 & 49.5 & 16.9 & 8.6 & 3.1 & 9.5 \\
\hline
\end{tabular}

the iron manganese oxide catalysts $([\mathrm{Fe}] /[\mathrm{Mn}]=1 / 1)$, the same amount (10 wt.\%) from each support has been added separately to a solution containing iron and manganese with above molar ratio. All of the different supported catalysts were tested for the selectivity of hydrogenation of CO. The CO conversion and hydrocarbons selectivity of the catalysts containing different supports are shown in Table 8. As it can be observed, the catalyst supported by $\mathrm{Al}_{2} \mathrm{O}_{3}$ is more active than the other supported catalysts and shows a high selectivity toward hydrocarbons. To understand the influence of loading of $\mathrm{Al}_{2} \mathrm{O}_{3}$ on the catalytic activity of mixed iron manganese oxide catalysts, a series of different $50 \% \mathrm{Fe} / 50 \% \mathrm{Mn} / \mathrm{wt} . \% \mathrm{Al}_{2} \mathrm{O}_{3}$ catalysts were prepared by coprecipitation procedure outlined above. The $\mathrm{Al}_{2} \mathrm{O}_{3}$ loadings were $5,10,20,25$, and $30 \mathrm{wt} \%$ based on the total catalyst weight and the catalytic performance results are shown in Table 9. According to these results, the catalysts loaded with $5 \mathrm{wt} . \% \mathrm{Al}_{2} \mathrm{O}_{3}$ showed the optimal catalytic performance for 


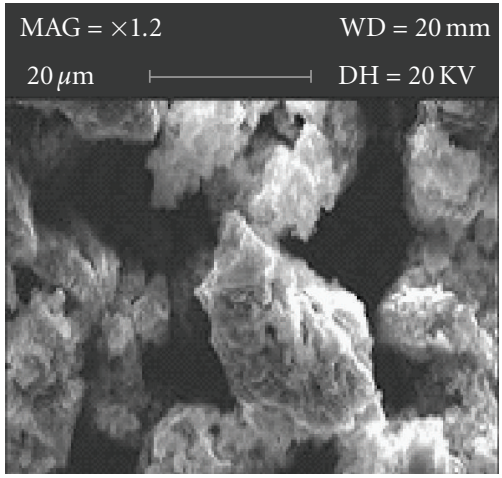

(a)

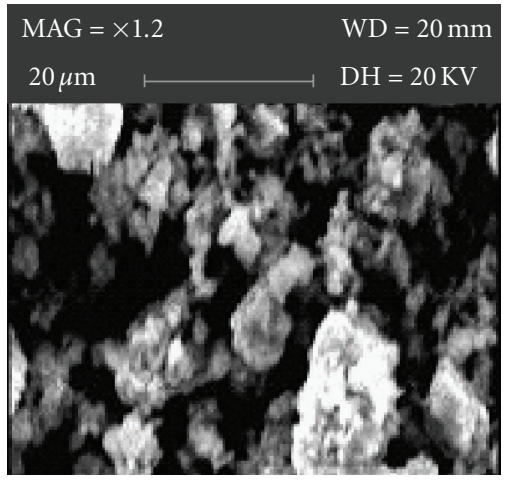

(b)

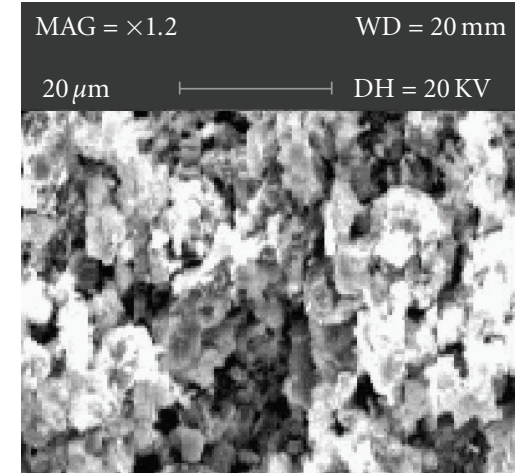

(c)

Figure 9: The SEM images of catalyst containing $50 \% \mathrm{Fe} / 50 \% \mathrm{Mn} / 5 \mathrm{wt} \% \mathrm{Al}_{2} \mathrm{O}_{3}$; (a) precursor, (b) calcined catalyst before reaction, and (c) calcined catalyst after reaction.

conversion of synthesis gas to light olefins. This catalyst was characterized by XRD and its patterns on different stages are shown in Figure 8. The actual phases identified in this catalyst were $\mathrm{Mn}_{5} \mathrm{O}_{8}$ (monoclinic), $\mathrm{Fe}_{2} \mathrm{O}_{3}$ (rhombohedral), and $\mathrm{Mn}_{2} \mathrm{O}_{3}$ (cubic) and its precursors comprised the $\mathrm{MnCO}_{3}$ phase with rhombohedral structure. In the tested catalyst, different phases including $\mathrm{FeO}$ (cubic), $\mathrm{MnO}$ (cubic), $\mathrm{Fe}_{3} \mathrm{O}_{4}$, and $\mathrm{Fe}_{2} \mathrm{C}$ (orthorombic) were identified. Characterization of both precursors and calcined-supported catalysts was carried out using BET surface area measurement and obtained results are presented in Table 14. In general, the BET results show that the catalyst precursors containing different supports and the calcined catalysts derived from these precursors have different specific surface area. However, as shown in Table 14, the catalyst precursors have higher specific surface areas than their calcined catalysts. Furthermore, the $\mathrm{Al}_{2} \mathrm{O}_{3}$ supported catalyst has a higher specific surface area than the other supported catalysts (Table 14), which is one reason for the better catalytic performance of this catalyst [38]. A detailed SEM study of the precursor calcined and tested catalysts for the sample containing optimum amount of $5 \mathrm{wt} \% \mathrm{Al}_{2} \mathrm{O}_{3}$ was also carried out. The SEM images of these catalysts are presented in Figure 9, and have shown the major differences in their morphology. By addition of $\mathrm{Al}_{2} \mathrm{O}_{3}$ as a support to the catalyst, the particle size of some grains has slightly increased and the supported catalyst revealed structural differences, which are probably due to the presence of $\mathrm{Al}_{2} \mathrm{O}_{3}$. This catalyst is comprised of large grains which are embedded in a mixture consisting of small grains (Figure 9(b)). However, the size of these grains grew larger by agglomeration in the tested catalyst (Figure 9(c)), which may be due to sintering after reactions. This result is in agreement with Galarraga [46], who indicate that high temperature could cause agglomeration of these small grains, which leads to catalyst deactivation under high temperature. The agglomeration is also caused by the imhomogenity distribution of metal precursor (Figure 9(a)).

3.1.6. Effect of Promoters. Alkali metals have been used widely as promoters to improve the activity and selec-
TABLE 10: Effect of different promoterson the catalytic performance of $50 \% \mathrm{Fe} / 50 \% \mathrm{Mn} / 5 \mathrm{wt} \% \mathrm{Al}_{2} \mathrm{O}_{3}$ catalyst.

\begin{tabular}{lcccccc}
\hline \multirow{2}{*}{ Promoter CO conversion (\%) } & \multicolumn{5}{c}{ Selectivity (\%) } \\
& & $\mathrm{CH}_{4}$ & $\mathrm{C}_{2} \mathrm{H}_{4}$ & $\mathrm{C}_{3} \mathrm{H}_{6}$ & $\mathrm{C}_{4} \mathrm{H}_{8}$ & $\mathrm{C}_{5}{ }^{+}$ \\
\hline $\mathrm{Rb}$ & 69.0 & 48.1 & 19.8 & 8.5 & 2.8 & 6.5 \\
$\mathrm{Mg}$ & 76.4 & 50.7 & 17.0 & 7.2 & 2.1 & 4.1 \\
$\mathrm{Li}$ & 73.2 & 45.9 & 18.5 & 7.4 & 1.7 & 11.8 \\
$\mathrm{~K}$ & 75.5 & 46.3 & 15.8 & 6.0 & 1.5 & 15.2 \\
\hline
\end{tabular}

tivity of the catalysts in the CO hydrogenation [47, 48]. To determine the utility of promoters on the catalytic performance of mixed iron manganese oxide catalysts, as alkali metals promoters, a small amount $(1.5 \mathrm{wt} . \%)$ of $\mathrm{LiNO}_{3}, \mathrm{KNO}_{3}, \mathrm{RbCl}$, and $\mathrm{Mg}\left(\mathrm{NO}_{3}\right)_{2} \cdot 6 \mathrm{H}_{2} \mathrm{O}$ were separately introduced to the resulting suspension containing $50 \% \mathrm{Fe} / 50 \% \mathrm{Mn} / 5 \mathrm{wt} \% \mathrm{Al}_{2} \mathrm{O}_{3}$. Then all of these different promoted catalysts were tested at the same reaction conditions $\left(400^{\circ} \mathrm{C}\right.$ and feed molar ratio of $\mathrm{H}_{2} / \mathrm{CO}=1 / 2$ at atmospheric pressure) for the conversion of synthesis gas to light olefins and the results are shown in Table 10. These results indicate that the addition of the $\mathrm{K}, \mathrm{Mg}, \mathrm{Li}$, and $\mathrm{Rb}$ promoters into the catalyst texture leads to a decrease on the selectivity of the catalyst toward light olefins. Thus taking these results into consideration, the catalyst containing $50 \% \mathrm{Fe} / 50 \% \mathrm{Mn} / 5 \mathrm{wt} . \% \mathrm{Al}_{2} \mathrm{O}_{3}$ without any promoter and aged for 3 hours appears to be the optimum-modified catalyst for the conversion of synthesis gas to light olefins.

3.2. Effect of FTS Reaction Conditions. The other category of factors which have a marked effect on the catalytic performance of a catalyst is the operating conditions. For optimizing of the reaction conditions in this study, the effects of operating conditions such as $\mathrm{H}_{2} / \mathrm{CO}$ feed molar ratios, reaction temperatures, and reactor total pressures were examined to investigate the catalyst stability and its performance under different Fischer-Tropsch operating conditions. 
TABle 11: Effect of different $\mathrm{H}_{2} / \mathrm{CO}$ feed molar ratios on the catalytic performance of $50 \% \mathrm{Fe} / 50 \% \mathrm{Mn} / 5 \mathrm{wt} \% \mathrm{Al}_{2} \mathrm{O}_{3}$ catalyst.

\begin{tabular}{lcccccc}
\hline \multirow{2}{*}{$\mathrm{H}_{2} / \mathrm{CO}$} & CO conversion (\%) & \multicolumn{5}{c}{ Selectivity (\%) } \\
& & $\mathrm{CH}_{4}$ & $\mathrm{C}_{2} \mathrm{H}_{4}$ & $\mathrm{C}_{3} \mathrm{H}_{6}$ & $\mathrm{C}_{4} \mathrm{H}_{8}$ & $\mathrm{C}_{5}{ }^{+}$ \\
\hline $1 / 1$ & 84.4 & 27.4 & 36.8 & 12.8 & 5.4 & 10.8 \\
$2 / 1$ & 80.9 & 30.5 & 34.7 & 12.5 & 5.4 & 7.1 \\
$3 / 1$ & 97.2 & 68.3 & 14.1 & 7.5 & 2.2 & 5.9 \\
\hline
\end{tabular}

TABLE 12: Effect of different reaction temperatures on the catalytic performance of $50 \% \mathrm{Fe} / 50 \% \mathrm{Mn} / 5 \mathrm{wt} \% \mathrm{Al}_{2} \mathrm{O}_{3}$ catalyst.

\begin{tabular}{lcccccc}
\hline \multirow{2}{*}{$T\left({ }^{\circ} \mathrm{C}\right)$} & CO conversion (\%) & \multicolumn{5}{c}{ Selectivity (\%) } \\
& & $\mathrm{CH}_{4}$ & $\mathrm{C}_{2} \mathrm{H}_{4}$ & $\mathrm{C}_{3} \mathrm{H}_{6}$ & $\mathrm{C}_{4} \mathrm{H}_{8}$ & $\mathrm{C}_{5}{ }^{+}$ \\
\hline 280 & 39.2 & 20.6 & 16.5 & 3.1 & 0.9 & 6.3 \\
300 & 49.8 & 23.5 & 17.3 & 3.5 & 1.8 & 5.7 \\
320 & 67.4 & 29.7 & 22.1 & 5.7 & 2.2 & 6.9 \\
340 & 84.4 & 27.4 & 36.8 & 12.8 & 5.4 & 5.4 \\
360 & 87.4 & 30.5 & 38.0 & 13.1 & 5.5 & 6.9 \\
380 & 87.1 & 34.9 & 32.2 & 9.1 & 2.9 & 5.3 \\
400 & 89.4 & 41.3 & 27.0 & 7.9 & 3.2 & 4.2 \\
430 & 80.3 & 40.5 & 24.2 & 8.2 & 3.7 & 5.7 \\
450 & 78.0 & 40.2 & 25.1 & 8.5 & 2.0 & 5.1 \\
\hline
\end{tabular}

3.2.1. Effect of $\mathrm{H}_{2} / \mathrm{CO}$ Molar Feed Ratio. The influence of the $\mathrm{H}_{2} / \mathrm{CO}$ molar feed ratio on the steady-state catalytic performance of the iron manganese oxide catalyst containing $50 \% \mathrm{Fe} / 50 \% \mathrm{Mn} / 5 \mathrm{wt} . \% \mathrm{Al}_{2} \mathrm{O}_{3}$ for the Fischer-Tropsch reaction at $400^{\circ} \mathrm{C}$ under atmospheric pressure was investigated and the $\mathrm{CO}$ conversion and light olefins products selectivity percent, present on steady-state catalytic performance, are presented in Table 11. The results showed that with variation in $\mathrm{H}_{2} / \mathrm{CO}$ feed ratio from $1 / 1$ to $3 / 1$, different selectivities with respect to light olefins were obtained. However, in the case of the $\mathrm{H}_{2} / \mathrm{CO}=1 / 1$, the total selectivity of light olefins products was higher and the $\mathrm{CH}_{4}$ selectivity was lower than the other $\mathrm{H}_{2} / \mathrm{CO}$ feed ratios under the same temperature and pressure condition. It is also apparent that, for all of the $\mathrm{H}_{2} / \mathrm{CO}$ feed molar ratios, the optimum catalyst shows a high selectivity toward ethylene. Therefore, the $\mathrm{H}_{2} / \mathrm{CO}=1 / 1$ ratio was chosen as the optimum ratio for conversion of synthesis gas to $\mathrm{C}_{2}-\mathrm{C}_{4}$ olefins over iron manganese catalysts.

3.2.2. Effect of Reaction Temperature. The effect of reaction temperature on the catalytic performance of the $50 \% \mathrm{Fe} / 50 \% \mathrm{Mn} / 5 \mathrm{wt} . \% \mathrm{Al}_{2} \mathrm{O}_{3}$ catalyst was studied at a range of temperature between $260-420^{\circ} \mathrm{C}$ and the results are presented in Table 12, $\left(P=1 \mathrm{~atm}, \mathrm{H}_{2} / \mathrm{CO}=1 / 1\right)$. The results show that as the operating temperature is increased, the $\mathrm{CO}$ conversion is increased. In addition, for the reaction temperature at $360^{\circ} \mathrm{C}$, the total selectivity of light olefins products was higher than the other reaction temperatures under the same reaction conditions. In general, an increase in the reaction temperature leads to an increase in the catalytic performance; furthermore, it has shown that the reaction temperature should not be too low [14]. At low reaction
TABLE 13: Effect of different total pressures on the catalytic performance of $50 \% \mathrm{Fe} / 50 \% \mathrm{Mn} / 5 \mathrm{wt} \% \mathrm{Al}_{2} \mathrm{O}_{3}$ catalyst.

\begin{tabular}{lcccccc}
\hline & & \multicolumn{5}{c}{ Selectivity $(\%)$} \\
Pressure (bar) & CO conversion (\%) & $\mathrm{CH}_{4}$ & $\mathrm{C}_{2} \mathrm{H}_{4}$ & $\mathrm{C}_{3} \mathrm{H}_{6}$ & $\mathrm{C}_{4} \mathrm{H}_{8}$ & $\mathrm{C}_{5}{ }^{+}$ \\
\hline 1 & 84.4 & 29.8 & 29.2 & 11.2 & 2.1 & 13.8 \\
2 & 84.0 & 26.5 & 30.7 & 11.9 & 2.6 & 15.6 \\
3 & 84.0 & 25.6 & 34.5 & 12.5 & 3.0 & 16.0 \\
4 & 84.1 & 25.1 & 37.2 & 12.8 & 3.2 & 17.5 \\
5 & 84.8 & 23.8 & 38.9 & 13.0 & 3.5 & 18.7 \\
6 & 84.0 & 19.8 & 40.1 & 13.2 & 5.9 & 20.5 \\
7 & 83.8 & 19.7 & 31.8 & 12.9 & 5.7 & 27.2 \\
8 & 82.2 & 19.5 & 31.2 & 12.1 & 5.3 & 29.6 \\
9 & 82.8 & 19.3 & 30.1 & 11.0 & 5.4 & 30.0 \\
10 & 78.2 & 19.0 & 28.0 & 10.3 & 3.5 & 34.4 \\
11 & 78.0 & 18.8 & 27.7 & 10.5 & 2.9 & 35.6 \\
12 & 76.6 & 18.0 & 27.1 & 9.2 & 2.7 & 38.0 \\
13 & 71.6 & 17.2 & 24.5 & 7.5 & 2.1 & 39.6 \\
14 & 68.2 & 16.7 & 22.2 & 7.2 & 2.0 & 41.7 \\
15 & 64.2 & 16.5 & 21.0 & 6.7 & 1.5 & 43.2 \\
\hline
\end{tabular}

TABLE 14: BET results for different supports on Fe/Mn catalysts.

\begin{tabular}{lccc}
\hline Support & Precursor & $\begin{array}{c}\text { Specific surface area }\left(\mathrm{m}^{2} / \mathrm{g}\right) \\
\text { Calcined catalyst } \\
\text { (before reaction) }\end{array}$ & $\begin{array}{c}\text { Calcined catalyst } \\
\text { (after reaction) }\end{array}$ \\
\hline $\mathrm{TiO}_{2}$ & 112.0 & 109.8 & 105.3 \\
$\mathrm{Zeolite}$ & 145.3 & 139.7 & 133.1 \\
$\mathrm{MgO}$ & 123.6 & 118.2 & 115.4 \\
$\mathrm{Al}_{2} \mathrm{O}_{3}$ & 157.5 & 152.3 & 150.7 \\
$\mathrm{SiO}_{2}$ & 165.6 & 148.2 & 142.6 \\
\hline
\end{tabular}

temperatures, the conversion percentage of $\mathrm{CO}$ is too low and so it causes a low-catalytic performance. On the other hand, increasing the reaction temperature leads to the formation of large amounts of coke as an unwanted product, as we found in this work. Therefore, in this study, $360^{\circ} \mathrm{C}$ is considered to be the optimum operating temperature because of high$\mathrm{CO}$ conversion, total selectivity of light olefins products, low $\mathrm{CH}_{4}$, and not formation of coke.

3.2.3. Effects of Total Pressure. An increase in total pressure would generally result in condensation of hydrocarbons, which are normally in the gaseous state at atmospheric pressure. Higher pressures and higher carbon monoxide conversions would probably lead to saturation of catalyst pores by liquid reaction products [49]. A different composition of the liquid phase in catalyst pores at high syngas pressures could affect the rate of elementary steps and carbon monoxide and hydrogen concentrations. A series of experiments were carried out for the $50 \% \mathrm{Fe} / 50 \% \mathrm{Mn} / 5 \mathrm{wt} . \% \mathrm{Al}_{2} \mathrm{O}_{3}$ catalyst to investigate on the performance of this catalyst in variation of total pressure in the range of $1-15 \mathrm{bar}$, at the optimal conditions of $\mathrm{H}_{2} / \mathrm{CO}=1 / 1$ and $360^{\circ} \mathrm{C}$ (Table 13). 
The results indicate that, at the total pressure of $1 \mathrm{bar}$, the optimal catalyst showed a total selectivity of $42.5 \%$ with respect to $\mathrm{C}_{2}-\mathrm{C}_{4}$ light olefins and $13.8 \%$ produce the $\mathrm{C}_{5}{ }^{+}$ products. It is also apparent that increasing in total pressure in the ranges of $2-15$ bar significantly increases the $\mathrm{C}_{5}{ }^{+}$ selectivity and leads to an increase to $43.2 \%$ at the pressure of 15 bar. In the other hand, as it can be seen on Table 13 at the ranges of 1-6 bar total pressures, no significant decreasing on CO conversion was observed, however, the light olefins selectivities were increased and the results indicate that at the total pressure of 6 bar, the optimal catalyst containing $50 \% \mathrm{Fe} / 50 \% \mathrm{Mn} / 5$ wt. $\% \mathrm{Al}_{2} \mathrm{O}_{3}$ showed the highest total selectivity of $59.2 \%$ with respect to $\mathrm{C}_{2}-\mathrm{C}_{4}$ light olefins and also led to $20.5 \%$ total of selectivity toward the $\mathrm{C}_{5}{ }^{+}$ products. The results also indicate that the $\mathrm{CO}$ conversion and the total selectivity with respect to $\mathrm{C}_{2}-\mathrm{C}_{4}$ light olefins were decreased as the total pressures are increased from 6 bar to 15 bar. Hence because of high $\mathrm{CO}$ conversion, low $\mathrm{CH}_{4}$ selectivity, and also higher total selectivity with respect to $\mathrm{C}_{2}-\mathrm{C}_{4}$ olefins at the total pressure of 6 bar, this pressure was chosen as the optimum pressure.

\section{Conclusions}

Many variables in the preparation of the catalyst during the coprecipitation procedure and the subsequent calcination step are important in controlling the catalytic performance of iron-manganese mixed oxide catalysts for conversion of synthesis gas to light olefins. Preparation conditions for optimum catalytic performance are $1 / 1:[\mathrm{Fe}] /[\mathrm{Mn}]$ ratio at $\mathrm{pH} 8.3$ and $70^{\circ} \mathrm{C}$ for 3 hours aging time, followed by calcination at $650^{\circ} \mathrm{C}$ for 6 hours. The optimal-supported catalyst was found to be $50 \% \mathrm{Fe} / 50 \% \mathrm{Mn} / 5 \mathrm{wt} . \% \mathrm{Al}_{2} \mathrm{O}_{3}$. The optimal reaction conditions were found to be $360^{\circ} \mathrm{C}$ with molar feed ratio of $\mathrm{H}_{2} / \mathrm{CO}=1 / 1,\left(\mathrm{GHSV}=2700 \mathrm{~h}^{-1}\right)$ under the total pressure of 6 bar. The characterization of both precursors and calcined catalysts by powder XRD, SEM, BET specific surface area, and thermal analysis (TGA/DSC) methods showed that the catalyst precursors are sensitive to the preparation conditions. Relationships between bulk phases and catalytic performance were complex, although the catalysts showed $\mathrm{X}$-ray diffraction features which correspond to amorphous mixed iron manganese oxide phases. The SEM results show that longer time enhances agglomerate size growth during reaction conditions which may be due to the formation of iron carbides as active phases for Fischer-Tropsch synthesis. From the results presented in this study, it is clear that the precipitation conditions used in the preparation procedure and also the operation conditions are of crucial importance and control of these parameters should be incorporated into the design of experimental programmers involving precipitation as the method of catalyst preparation and design of catalytic reactor as the method of operation conditions.

\section{References}

[1] D. J. Duvenhage and N. J. Coville, "Fe: $\mathrm{Co} / \mathrm{TiO}_{2}$ bimetallic catalysts for the Fischer-Tropsch reaction I. Characterization and reactor studies," Applied Catalysis A, vol. 153, no. 1-2, pp. 43-67, 1997.

[2] C. Cabet, A. C. Roger, A. Kiennemann, S. Läkamp, and G. Pourroy, "Synthesis of new Fe-Co based metal/oxide composite materials: application to the Fischer-Tropsch synthesis," Journal of Catalysis, vol. 173, no. 1, pp. 64-73, 1998.

[3] S. L. González-Cortés, S. M. A. Rodulfo-Baechler, A. Oliveros, et al., "Synthesis of light alkenes on manganese promoted iron and iron-cobalt Fischer-Tropsch catalysts," Reaction Kinetics and Catalysis Letters, vol. 75, no. 1, pp. 3-12, 2002.

[4] F. Tihay, G. Pourroy, M. Richard-Plouet, A. C. Roger, and A. Kiennemann, "Effect of Fischer-Tropsch synthesis on the microstructure of $\mathrm{Fe}$-Co-based metal/spinel composite materials," Applied Catalysis A, vol. 206, no. 1, pp. 29-42, 2001.

[5] F. Tihay, A. C. Roger, A. Kiennemann, and G. Pourroy, "FeCo based metal/spinel to produce light olefins from syngas," Catalysis Today, vol. 58, no. 4, pp. 263-269, 2000.

[6] T. V. Reshetenko, L. B. Avdeeva, A. A. Khassin, et al., "Coprecipitated iron-containing catalysts $\left(\mathrm{Fe}-\mathrm{Al}_{2} \mathrm{O}_{3}, \mathrm{Fe}-\mathrm{Co}-\right.$ $\mathrm{Al}_{2} \mathrm{O}_{3}, \mathrm{Fe}-\mathrm{Ni}-\mathrm{Al}_{2} \mathrm{O}_{3}$ ) for methane decomposition at moderate temperatures I. Genesis of calcined and reduced catalysts," Applied Catalysis A, vol. 268, no. 1-2, pp. 127-138, 2004.

[7] V. A. de la Peña O’Shea, N. N. Menéndez, J. D. Tornero, and J. L. G. Fierro, "Unusually high selectivity to $\mathrm{C}_{2+}$ alcohols on bimetallic CoFe catalysts during $\mathrm{CO}$ hydrogenation," Catalysis Letters, vol. 88, no. 3-4, pp. 123-128, 2003.

[8] M. E. Dry, "The Fischer-Tropsch synthesis," in Catalysis Science and Technology, J. R. Anderson and M. E. Boudart, Eds., vol. 1, pp. 159-255, Springer, New York, NY, USA, 1981.

[9] D. L. King, J. A. Cusumano, and R. L. Garten, "A technological perspective for catalytic processes based on synthesis gas," Catalysis Reviews, vol. 23, no. 1-2, pp. 233-263, 1981.

[10] G. C. Maiti, R. Malessa, and M. Baerns, "Iron/manganese oxide catalysts for Fischer-Tropsch synthesis-part I: structural and textural changes by calcination, reduction and synthesis," Applied Catalysis, vol. 5, no. 2, pp. 151-170, 1983.

[11] R. Malessa and M. Baerns, "Iron/manganese oxide catalysts for Fischer-Tropsch synthesis. 4. Activity and selectivity," Industrial and Engineering Chemistry Research, vol. 27, no. 2, pp. 279-283, 1988.

[12] H. Kölbel and K. D. Tillmetz, " Process for the production of hydrocarbons and oxygen-containing compounds and catalysts therefor," US patent no. 4177203, 1979.

[13] C. K. Das, N. S. Das, D. P. Choudhury, G. Ravichandran, and D. K. Chakrabarty, "Hydrogenation of carbon monoxide on unsupported $\mathrm{Fe}-\mathrm{Mn}-\mathrm{K}$ catalysts for the synthesis of lower alkenes: promoter effect of manganese," Applied Catalysis A, vol. 111, no. 2, pp. 119-132, 1994.

[14] J. Barrault, C. Forquy, and V. Perrichon, "Effects of manganese oxide and sulphate on olefin selectivity of iron supported catalysts in the Fischer-Tropsch reaction," Applied Catalysis, vol. 5, no. 1, pp. 119-125, 1983.

[15] G. P. Van der Laan and A. A. C. M. Beenackers, "Kinetics and selectivity of the Fischer-Tropsch synthesis: a literature review," Catalysis Reviews, vol. 41, no. 3-4, pp. 255-318, 1999.

[16] S. L. González-Cortés, S. M. A. Rodulfo-Baechler, A. Oliveros, et al., "Synthesis of light alkenes on manganese promoted iron and iron-cobalt Fischer-Tropsch catalysts," Reaction Kinetics and Catalysis Letters, vol. 75, no. 1, pp. 3-12, 2002.

[17] J. B. Butt, "Carbide phases on iron-based Fischer-Tropsch synthesis catalysts-part II: some reaction studies," Catalysis Letters, vol. 7, no. 1-4, pp. 83-105, 1990. 
[18] Y. Liu, B.-T. Teng, X.-H. Guo, et al., "Effect of reaction conditions on the catalytic performance of Fe-Mn catalyst for Fischer-Tropsch synthesis," Journal of Molecular Catalysis A, vol. 272, no. 1-2, pp. 182-190, 2007.

[19] T. Li, Y. Yang, C. Zhang, et al., "Effect of manganese on an iron-based Fischer-Tropsch synthesis catalyst prepared from ferrous sulfate," Fuel, vol. 86, no. 7-8, pp. 921-928, 2007.

[20] Y. Yang, H.-W. Xiang, L. Tian, et al., "Structure and FischerTropsch performance of iron-manganese catalyst incorporated with $\mathrm{SiO}_{2}$," Applied Catalysis A, vol. 284, no. 1-2, pp. 105-122, 2005.

[21] T. Herranz, S. Rojas, F. J. Pérez-Alonso, M. Ojeda, P. Terreros, and J. L. G. Fierro, "Hydrogenation of carbon oxides over promoted Fe-Mn catalysts prepared by the microemulsion methodology," Applied Catalysis A, vol. 311, no. 1-2, pp. 6675, 2006.

[22] C.-H. Zhang, Y. Yang, B.-T. Teng, et al., "Study of an ironmanganese Fischer-Tropsch synthesis catalyst promoted with copper," Journal of Catalysis, vol. 237, no. 2, pp. 405-415, 2006.

[23] H. Schultz and H. Gökcebay, "Fischer-Tropsch COhydrogenation as a means for linear olefins production," in Catalysis of Organic Reactions, J. R. Kosak, Ed., pp. 153-169, Marcel Dekker, New York, NY, USA, 1984.

[24] H. Kölbel and K. D. Tillmetz, "Hydrocarbons and oxygen containing compounds," Belgian Patent, no. 237 628, 1976.

[25] C. H. Bartholomew, "History of cobalt catalyst design for FTS," in Proceedings of the National Spring Meeting of the American Institute of Chemical Engineers (AIChE '03), New Orleans, La, USA, March-April 2003.

[26] N.-O. Ikenaga, H. Taniguchi, A. Watanabe, and T. Suzuki, "Sulfiding behavior of iron based coal liquefaction catalyst," Fuel, vol. 79, no. 3-4, pp. 273-283, 2000.

[27] G. J. Hutchings, A. A. Mirzaei, R. W. Joyner, M. R. H. Siddiqui, and S. H. Taylor, "Ambient temperature CO oxidation using copper manganese oxide catalysts prepared by coprecipitation: effect of ageing on catalyst performance," Catalysis Letters, vol. 42, no. 1-2, pp. 21-24, 1996.

[28] G. J. Hutchings, A. A. Mirzaei, R. W. Joyner, M. R. H. Siddiqui, and S. H. Taylor, "Effect of preparation conditions on the catalytic performance of copper manganese oxide catalysts for CO oxidation," Applied Catalysis A, vol. 166, no. 1, pp. 143152, 1998.

[29] S. H. Taylor, G. J. Hutchings, and A. A. Mirzaei, "Copper zinc oxide catalysts for ambient temperature carbon monoxide oxidation," Chemical Communications, no. 15, pp. 1373-1374, 1999.

[30] D. M. Whittle, A. A. Mirzaei, J. S. J. Hargreaves, et al., "Coprecipitated copper zinc oxide catalysts for ambient temperature carbon monoxide oxidation: effect of precipitate ageing on catalyst activity," Physical Chemistry Chemical Physics, vol. 4, no. 23, pp. 5915-5920, 2002.

[31] A. A. Mirzaei, H. R. Shaterian, R. W. Joyner, M. Stockenhuber, S. H. Taylor, and G. J. Hutchings, "Ambient temperature carbon monoxide oxidation using copper manganese oxide catalysts: effect of residual $\mathrm{Na}^{+}$acting as catalyst poison," Catalysis Communications, vol. 4, no. 1, pp. 17-20, 2003.

[32] A. A. Mirzaei, H. R. Shaterian, M. Habibi, G. J. Hutchings, and S. H. Taylor, "Characterisation of copper-manganese oxide catalysts: effect of precipitate ageing upon the structure and morphology of precursors and catalysts," Applied Catalysis A, vol. 253, no. 2, pp. 499-508, 2003.
[33] A. A. Mirzaei, H. R. Shaterian, S. H. Taylor, and G. J. Hutchings, "Co-precipitated copper zinc oxide catalysts for ambient temperature carbon monoxide oxidation: effect of precipitate aging atmosphere on catalyst activity," Catalysis Letters, vol. 87, no. 3-4, pp. 103-108, 2003.

[34] S. H. Taylor, G. J. Hutchings, and A. A. Mirzaei, "The preparation and activity of copper zinc oxide catalysts for ambient temperature carbon monoxide oxidation," Catalysis Today, vol. 84, no. 3-4, pp. 113-119, 2003.

[35] A. A. Mirzaei, H. R. Shaterian, and M. Kaykhaii, "The X-ray photoelectron spectroscopy of surface composition of aged mixed copper manganese oxide catalysts," Applied Surface Science, vol. 239, no. 2, pp. 246-254, 2005.

[36] A. A. Mirzaei, R. Habibpour, and E. Kashi, "Preparation and optimization of mixed iron cobalt oxide catalysts for conversion of synthesis gas to light olefins," Applied Catalysis A, vol. 296, no. 2, pp. 222-231, 2005.

[37] A. A. Mirzaei, M. Faizi, and R. Habibpour, "Effect of preparation conditions on the catalytic performance of cobalt manganese oxide catalysts for conversion of synthesis gas to light olefins," Applied Catalysis A, vol. 306, pp. 98-107, 2006.

[38] A. A. Mirzaei, R. Habibpour, M. Faizi, and E. Kashi, "Characterization of iron-cobalt oxide catalysts: effect of different supports and promoters upon the structure and morphology of precursors and catalysts," Applied Catalysis A, vol. 301, no. 2, pp. 272-283, 2006.

[39] A. A. Mirzaei, M. Galavy, A. Beigbabaei, and V. Eslamimanesh, "Preparation and operating conditions for cobalt cerium oxide catalysts used in the conversion of synthesis gas into light olefins," Journal of the Iranian Chemical Society, vol. 4, no. 3, pp. 347-363, 2007.

[40] A. A. Mirzaei, M. Galavy, and V. Eslamimanesh, "SEM and BET methods for investigating the structure and morphology of coCe catalysts for production of light olefins," Australian Journal of Chemistry, vol. 61, no. 2, pp. 144-152, 2008.

[41] H.-B. Zhang and G. L. Schrader, "Characterization of a fused iron catalyst for Fischer-Tropsch synthesis by in situ laser Raman spectroscopy," Journal of Catalysis, vol. 95, no. 1, pp. 325-332, 1985.

[42] M. D. Shroff, D. S. Kalakkad, K. E. Coulter, et al., "Activation of precipitated iron Fischer-Tropsch synthesis catalysts," Journal of Catalysis, vol. 156, no. 2, pp. 185-207, 1995.

[43] Y. Yang, H.-W. Xiang, Y.-Y. Xu, L. Bai, and Y.-W. Li, "Effect of potassium promoter on precipitated iron-manganese catalyst for Fischer-Tropsch synthesis," Applied Catalysis A, vol. 266, no. 2, pp. 181-194, 2004.

[44] D. L. King, "A Fischer-Tropsch study of supported ruthenium catalysts," Journal of Catalysis, vol. 51, no. 3, pp. 386-397, 1978.

[45] R. C. Reuel and C. H. Bartholomew, "Effects of support and dispersion on the CO hydrogenation activity/selectivity properties of cobalt," Journal of Catalysis, vol. 85, no. 1, pp. 78-88, 1984.

[46] C. E. Galarraga, Heterogeneous catalyst for the synthesis of middle distillate hydrocarbons, M.S. thesis, University of Western Ontario, London, Canada, 1998.

[47] H. A. Dirkse, P. W. Lednor, and P. C. Versloot, "Alkali metal-naphthalene adducts as reagents for neutralizing oxide surfaces, and the effect of alkali metal treated surfaces in Rhcatalysed synthesis gas $\left(\mathrm{CO}+\mathrm{H}_{2}\right)$ conversion," Journal of the Chemical Society, Chemical Communications, no. 14, pp. 814815, 1982. 
[48] J. Gaube, K. Herzog, L. König, and B. Schliebs, "Kinetische untersuchungen der Fischer-Tropsch-Synthese zur klärung der wirkung des alkali als promotor in eisen-katalysatoren," Chemie Ingenieur Technik, vol. 58, no. 8, pp. 682-683, 1986.

[49] A. Griboval-Constant, A. Y. Khodakov, R. Bechara, and V. L. Zholobenko, "Support mesoporosity: a tool for better control of catalytic behavior of cobalt supported Fischer-Tropsch catalysts," Studies in Surface Science and Catalysis, vol. 144, pp. 609-616, 2002. 


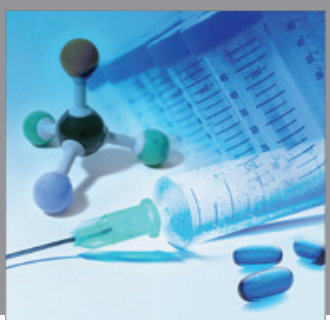

International Journal of

Medicinal Chemistry

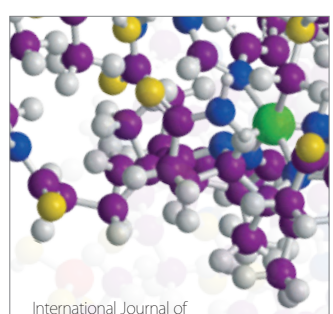

Carbohydrate Chemistry

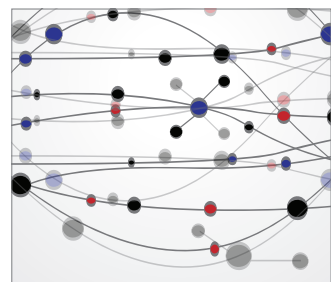

The Scientific World Journal
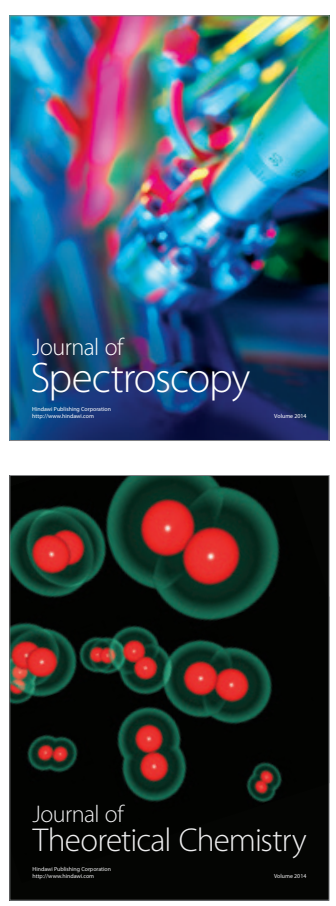
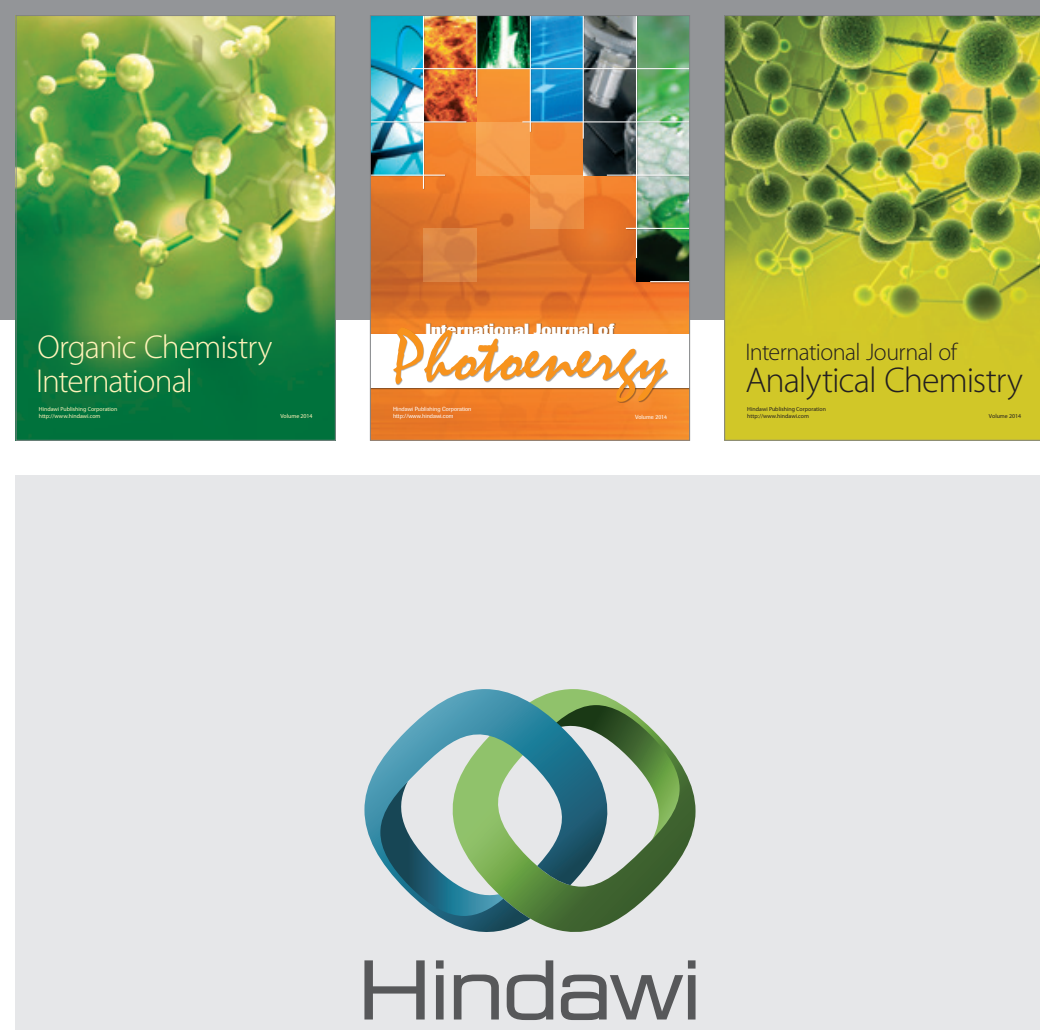

Submit your manuscripts at

http://www.hindawi.com
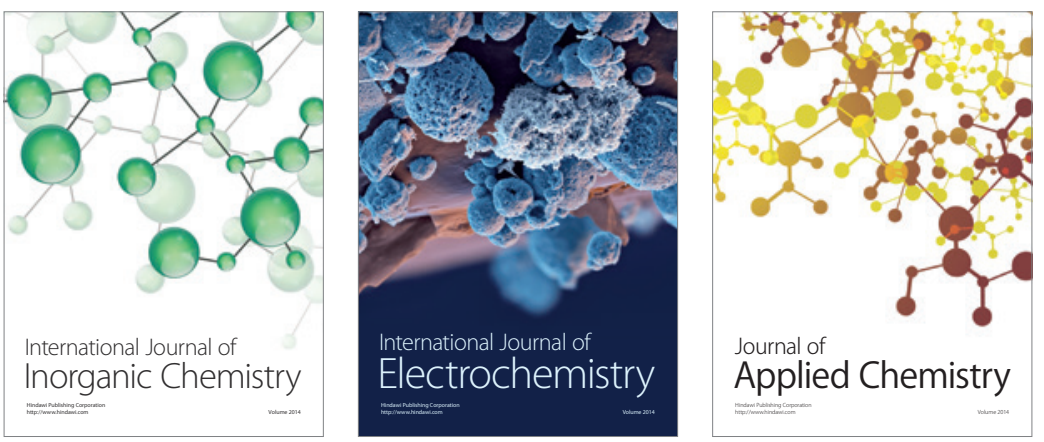

Journal of

Applied Chemistry
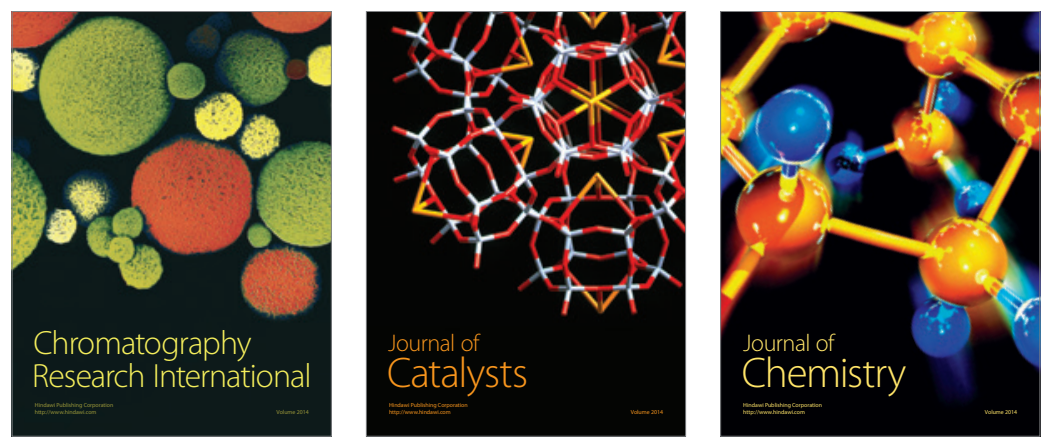
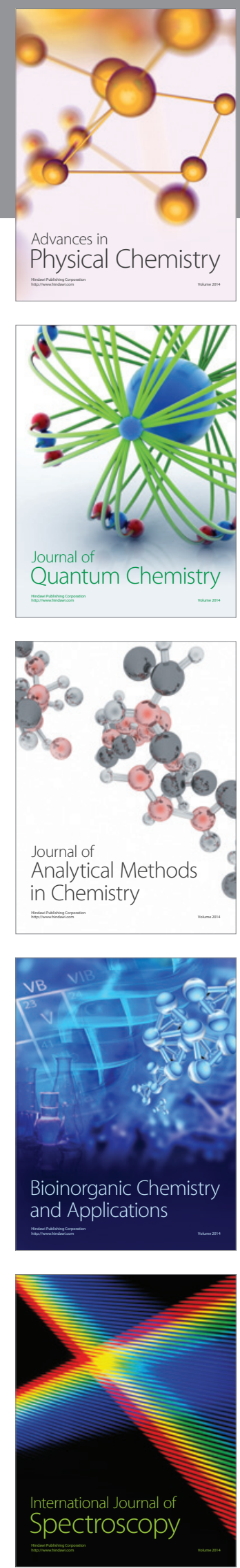